\title{
CEMENTED NbC-Co FOR GEOTHERMAL DRILLING APPLICATIONS
}

Final Report

May 1987

By: David J. Rowcliffe

Materials Research Laboratory

Prepared for:

SANDIA NATIONAL LABORATORY

Division 3731

P.O. Box 5800

Albuquerque, NM 87185

Attention: Mr. John Finger

SRI Project PYC-8023

SRI International

333 Ravenswood Avenue

Menlo Park, California 94025-3493

(415) 326-6200

TWX: 910-373-2046

Telex: 334486 


\section{DISCLAIMER}

This report was prepared as an account of work sponsored by an agency of the United States Government. Neither the United States Government nor any agency Thereof, nor any of their employees, makes any warranty, express or implied, or assumes any legal liability or responsibility for the accuracy, completeness, or usefulness of any information, apparatus, product, or process disclosed, or represents that its use would not infringe privately owned rights. Reference herein to any specific commercial product, process, or service by trade name, trademark, manufacturer, or otherwise does not necessarily constitute or imply its endorsement, recommendation, or favoring by the United States Government or any agency thereof. The views and opinions of authors expressed herein do not necessarily state or reflect those of the United States Government or any agency thereof. 


\section{DISCLAIMER}

Portions of this document may be illegible in electronic image products. Images are produced from the best available original document. 


\section{CEMENTED NbC-Co FOR GEOTHERMAL DRILLING APPLICATIONS}

Final Report

May 1987

By: David J. Rowcliffe

Materials Research Laboratory

Prepared for:

SANDIA NATIONAL LABORATORY

Division 3731

P.O. Box 5800

Albuquerque, NM 87185

Attention: Mr. John Finger

SRI Project PYC-8023

Approved by:

D. L. Hildenbrand, Director

Materials Research Laboratory

G. R. Abrahamson

Vice President

Physical Sciences Division 
SUMMARY

Sintering and hot isostatic pressing were explored to produce a range of $\mathrm{NbC}-\mathrm{Co}$ materials. Stolchiometric $\mathrm{MbC}-10 \mathrm{Co}$ and $\mathrm{NbC}-20 \mathrm{Co}$ were sintered close to the theoretical density relatively easily. Cemented

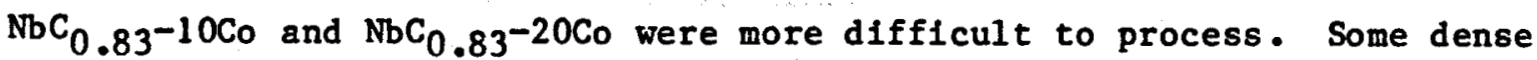
materials were prepared by combination of sintering and hot isostatic pressing at $1420^{\circ}$ to $1450^{\circ} \mathrm{C}$. The carbide in these samples appeared to have the composition $\mathrm{NbC}_{0.9}$. Hardness, toughness, and wear tests showed that the properties of these $\mathrm{NbC}_{0.9-10 \mathrm{Co}}$ samples were inferior to those

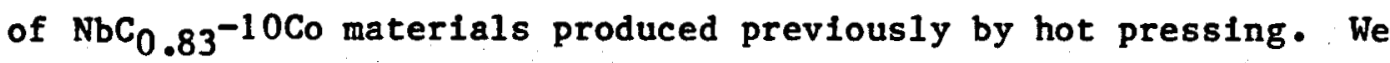
concluded that contamination from WC miling balls and excessive processing times were the main causes of the difficulty in controlling the composition and properties of substoichiometric cemented niobium carbide. 
SUMMARY

LIST OF TABLES $\ldots \ldots \ldots \ldots \ldots \ldots \ldots \ldots \ldots \ldots \ldots \ldots \ldots \ldots \ldots \ldots \ldots \ldots \ldots \ldots \ldots \ldots$. $\ldots \ldots$

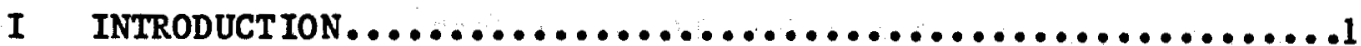

II EXPER IMENTAL PROCEDURES $\ldots \ldots \ldots \ldots \ldots \ldots \ldots \ldots \ldots \ldots \ldots \ldots \ldots \ldots \ldots \ldots \ldots 3$

Fabrication Methods .................................3

Evaluation Techniques .............................7

III RESULTS AND DISCUSSION $\ldots \ldots \ldots \ldots \ldots \ldots \ldots \ldots \ldots \ldots \ldots \ldots \ldots \ldots \ldots \ldots$

Fabrication Studies.............................9

Microstructural Studies..........................12

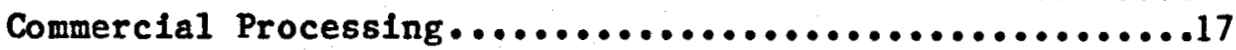

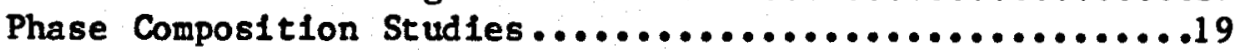

Evaluation of Toughness, Hardness and Wear Resistance...21

General Discusston..............................22

IV CONCLUSIONS $\ldots \ldots \ldots \ldots \ldots \ldots \ldots \ldots \ldots \ldots \ldots \ldots \ldots \ldots \ldots \ldots \ldots \ldots \ldots . \ldots \ldots$ 
1. Powder Sources And Sizes $\ldots \ldots \ldots \ldots \ldots \ldots \ldots \ldots \ldots \ldots \ldots \ldots \ldots \ldots, \ldots$

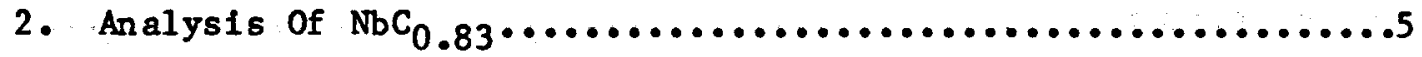

3. Oxygen And Carbon Analyses......................... .6

4. Preparation Conditions For NbC-Co Powders ................10

5. Fabrication Data For Cemented Niobium Carbides..............11 Sintered At The Same Temperature

6. Fabrication Data For Cemented Niobi um Carbides $\ldots . \ldots \ldots \ldots \ldots 16$ Sintered At Various Temperature

7. Wear Resistance of Cemented Carbides.....................22

\section{LIST OF FIGURES}

Figure 1. Microstructures of $\mathrm{NbC}_{\mathrm{x}}$-Co materials sintered.........13 at $1450^{\circ} \mathrm{C}$ (a) $\mathrm{NbC}_{0.83^{-10 C o}}$ (b) $\mathrm{NbC}-20 \mathrm{Co}$ (c) $\mathrm{NbC}_{0.83^{-20 \mathrm{Co}}}$

Figure 2. Microstructures of $\mathrm{NbC}_{\mathrm{x}}-\mathrm{Co}$ materials sintered ........15 at $1400^{\circ} \mathrm{C}$ (a) $\mathrm{NbC}_{0.83^{-1}} 0 \mathrm{Co}$ (b) $\mathrm{NbC}_{0.83^{-20 C o}}$ (c) $\mathrm{NbC}-10 \mathrm{Co}$ (d) $\mathrm{NbC}-20 \mathrm{Co}$

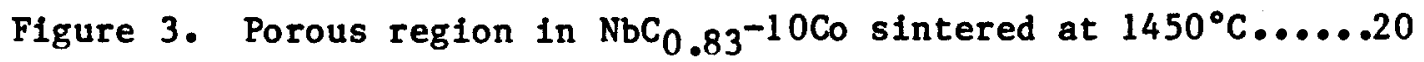


Cemented WC-Co is extensively used for both geothermal and o1l drilling. These applications demand a range of cutting Insert materials In which different combinations of hardness, toughness, and strength permit effective drilling in a varlety of rock formations. of the many cemented carbldes that have been developed commerclally, only the unalloyed WC-Co grades are sultable for rock cutting. Additions of TiC or other cublc carbides improve the performance of WC-Co in metal cutting applications, but these multicomponent grades and other cemented carbides based on TIC are less effective as rock-bit Inserts: By experience, rock-b1t manufacturers are able to spec1fy grades of WC-Co that are approprlate for different drilling conditions, but a fundamental understanding of the Importance and interplay of materials properties is lacking.

In WC-Co, the cobalt content and the WC grain size are the main parameters that are used to vary the mechanical properties. Commercial rock cutting grades contain 8 , to $16 \mathrm{wt \%}$ Co and the WC grain size can be from 0.5 to $5 \mathrm{\mu m}$. These materlals have Vickers hardness of 10-17 GPa, compressive strengths of 4000-7000 MPa, and fracture toughnesses of 18-8 $\mathrm{MPa} \frac{1}{1 / 2}$ Hardness and strength Increase with both decreasing WC grain size and decreasing co content. For a given WC grain size, the fracture toughness of WC-Co Increases with increasing $\mathrm{Co}$, and for a given co content, coarse-grained wC-Co is tougher than fine-grained materials.

Within Iimits, higher hardness and resistance to abresive wear can thus be developed at the expense of toughness. However, as the hardness and brittleness Increase, the wear mechanisms change from those in which plastic deformation is important to others that are dominated by elastic micro and macrofracture. One approach to improving the performance of b1t-inserts $1 \mathrm{~s}$ to look for systems in which the hardness of the composite is not so closely tied to the fracture toughness, as is the case for WC- 
Co. Cemented nioblum carbide $\mathrm{NbC}_{\mathrm{x}}$ (where $\mathrm{x}$ is approximately 0.6 to 0.96), offers such a possibility. The hardness of NbC $\times$ depends strongly on carbon content with a maximum hardness close to $\mathrm{NbC}_{0.83}$. In contrast, WC is a stoichiometric compound and loss of carbon causes the formation of $\mathrm{W}_{2} \mathrm{C}$. Thus, in cemented $\mathrm{NbC}_{x}$ the factors controlling properties are cobalt content, carbide grain size, and carbon content of the carbide.

In a previous study, a range of cemented carbides based on $\mathrm{NbC}_{\mathrm{x}}$ and $\mathrm{TaC}_{\mathrm{x}}$ (tantalum carbide) with $\mathrm{CO}_{\text {and }} \mathrm{N} 1$ binders was fabricated and evaluated. 1 Hardness, fracture toughness, and abrasive wear resistance were measured for hot-pressed materials and compared with data for

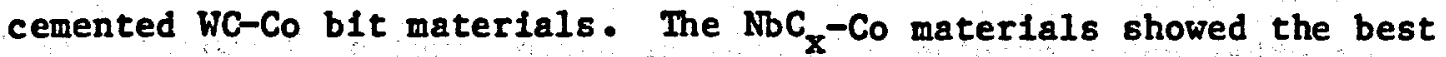
combination of properties. It was found that, for compositions with the same hardness, the fracture toughness of $\mathrm{MbC}_{0.83^{-}} \mathrm{Co}_{0}$ was greater than that of stolchlometric NbC-Co. In addition, abrasive wear tests showed that the wear-resistance of $\mathrm{NbC}_{x}$-Co lles within the range of wear resistance of grades of WC-Co commonly used in rock-cutting. From these results it was concluded that by adjusting the carbon content of the carbide it is possible to obtain simultaneous improvements in hardness and toughness in this system.

In the previous project, all materials were prepared by hot pressing and some nonuniformity of microstructure and evidence for residual stresses were thought to be assoclated with the processing technique. The goals of the present project were to establish a sintering route for $\mathrm{NbC}_{\mathrm{x}}$-Co materials, to evaluate their properties, and to produce samples suitable for rock drilling tests.

1 D. J. Rowcliffe "Development of a New Family of Cemented Carbides for Geothermal Drilling," SRI Final Report on Sand1a Contract 74-4755 (May 1983). 


\section{EXPER DMENTAL PROCEDURES}

\section{Fabrication Methods}

Table 1 lists powder sources and particle sizes. The substolchiometric $\mathrm{NbC}_{0.83}$ was specially prepared at Wah Chang by reacting the approprlate amount of $\mathrm{Nb}$ powder with stolchiometric NbC powder. The manufacturers analysis is given in Table 2. The carbon contents of several $\mathrm{NbC}_{\mathrm{x}}$ powders were determined by combustion, ${ }^{*}$ and the oxygen contents were measured by fast neutron activation. ${ }^{\dagger}$ These data, which are given In Table 3, show good agreement with the data of Table 2. In addition, lattice parameters of $\mathrm{NbC}_{\mathrm{x}}$ samples were measured by $x$-ray diffraction and compared with published data on the dependence of lattice constants on carbon content..$^{2}$ The agreement between the measured carbon contents and those estimated from the lattice parameter was within $2 \%$ for carbides of nominal composition $\mathrm{NbC}_{0.83^{\circ}}$. The lattice parameter of the nominally stoichlometrlc NbC was $4.4709 \AA$, as expected. However, the carbon analysis shown in Table 3 for this material corresponds to $\mathrm{NbC}_{0.95}$. This discrepancy is related to the high oxygen content $(0.63 \%)$ of the fine stolchlometric powder. A calculation of the composition gave a metal/nonmetal molar ratio of unity, indicating that oxygen had substituted for an equivalent quantity of carbon in the NbC lattice.

Approximately 25 batches of $\mathrm{Nb}_{x}$-Co powders were prepared by elther ball milling or planetary milling using WC milling balls in polyethylene contalners. Batches of approximately $80 \mathrm{~g}$ were milled with 2 wt\% polyethylene glycol (Carbowax 4000) dissolved in deoxidized, delonized water or methanol. Both evaporative drying and spray drying were used to remove the solvent. Several $100 \mathrm{~g}$ batches and an additional $3 \mathrm{~kg}$ batch of $\mathrm{NbC}_{0.83^{-10}} \mathrm{Co}_{0}$ was prepared using paraffin wax in a solvent of hexane.

* Stanford University, Stanford, CA.

t IRT Corp, San Diego, CA.

2 E. K. Storms, The Refractory Carbide (Academic Press, 1967), p. 67 . 
Table 1

POWDER SOURCES AND SIZES

$\frac{\text { Powder }}{\text { Stoichlometric NbC }}$
$\mathrm{NbC}_{0.83}$
$\mathrm{Co}$
Co

Source

Herman Starck

Wah Chang

Herman Starck

African Metals
Size

2 Hom -325 mesh, FSSS 16 m $2 \mathrm{Hm}$

2 III 
Table 2

ANALYSIS OF $\mathrm{NbC}_{0.83}$

Element

0

N

Fe

Al

S1

$\mathrm{Ta}$

$\mathrm{TI}$

$\mathrm{Zr}$

Hf

B

Cd

co

Cr

Cu

$\mathrm{Mg}$

Mn

Mo

Ni

$\mathrm{Pb}$

Sn

v

W

$\mathrm{zn}$

C

Free C
Results (ppm)

160

170

$<50$

22

$<50$

1390

$<55$

$<100$

560

4

$<5$

$<10$

20

$<40$

$<20$

$<20$

$<50$

$<20$

$<20$

$<10$

20

180

$<10$

$9.75 \%, 9.77 \%$

$0.05 \%$ 
Table 3

OXYGEN AND CARBON ANALYSES

\begin{tabular}{lccc}
$\begin{array}{c}\text { Material } \\
\text { Material }\end{array}$ & $\begin{array}{c}\text { Carbon } \\
(\text { wt\% })\end{array}$ & $\begin{array}{c}\text { Oxygen } \\
(\text { wt\% })\end{array}$ & $\begin{array}{c}\text { Corresponding } \\
\text { Carbide Compositon }\end{array}$ \\
\hline SRI NbC 0.83 & 9.43 & -- & $\mathrm{NbC}_{0.81}$ \\
Starck NbC & 10.93 & 0.63 & $\mathrm{NbC}_{0.95}$ \\
Wah Chang NbC $0.83^{a}$ & & & \\
No. 1 & 9.62 & 0.031 & $\mathrm{NbC}_{0.82}$ \\
No. 2 & 9.76 & 0.031 & $\mathrm{NbC}_{0.84}$ \\
Starck Co & - & 1.2 & -
\end{tabular}

a No. 1 and No. 2 were separate samples from the main batch. 
Inftially, cylindrical rods approximately 10 m long by $12.5 \mathrm{~mm}$ in diameter were cold pressed with a range of pressures to define the pressures and corresponding green sizes that would sinter to full density. Based on the shrinkage data from these experiments, a die was machined to fabricate rods that would sinter to the dimensions of shortrod fracture toughness and wear test specimens (19 mm by $12.7 \mathrm{~mm}$ in diameter), and most samples prepared during the project were of this size.

Pressed cylinders were dewaxed in a horizontal tube furnace equipped with a programmable controller and fac1litles to control the environment. All samples were dewaxed in hydrogen. A typical dewaxing cycle was as follows: $25^{\circ}$ to $250^{\circ} \mathrm{C}$ at $2^{\circ}$ to $3^{\circ} \mathrm{C} / \mathrm{per}$ minute, hold at $250^{\circ} \mathrm{C}$ for 10 minutes, $250^{\circ}$ to $400^{\circ} \mathrm{C}$ at $2^{\circ} \mathrm{C} /$ minute, $400^{\circ}$ to $600^{\circ} \mathrm{C}$ at $5^{\circ} /$ minute, hold up to 2 hours at $600^{\circ} \mathrm{C}$.

Dewaxed samples were stored under hydrogen until they were needed for further processing. Some samples were sintered in a carbon resistance furnace under pressures of argon up to 20 atm at temperatures between $1400^{\circ}$ and $1550^{\circ} \mathrm{C}$. Other samples were sintered under $1 \mathrm{~atm}$ of argon in a hot 1sostatic press. After sufficient time to close most pores ( $1 / 2$ to 1 hour), the system was pressurlzed in an effort to reach full density. Several experimental samples were processed at Progressive Carbide by a similar sinter-HIP process, using a final pressure of 225 psi. Other samples were hot isostatically pressed at Reed Rock Bit. Evaluation Techniques

Welght $10 s s e s$ and dimenslonal changes were determined after dewaxing and after sintering or hot 1sostatic pressing. Densities of sintered samples were measured by welghing in alr and in alcohol. Metallographic samples were prepared by conventional dlamond pollshing, finishing with 1- $\mu_{m}$ paste. Some samples were etched in Nital or Murakaml's reagent.

Hardness and Indentation toughness measurements were made on polished surfaces using either a standard Vickers machine with loads up to $100 \mathrm{~kg}$ or a Leltz microhardness system with loads up to $2 \mathrm{~kg}$. Some 
fracture toughness measurements were made at Terratek using the short-rod technique. Wear tests were performed at the Security Division of Dresser Industries, using a proprietary method that determines the volume of material lost from a test piece that has been drawn across a rock slab under controlled conditions. Wear surfaces, fracture surfaces, and metallographic specimens were examined by scanning electron microscopy (SEM) using energy dispersive $x$-ray analysis to Identify elements. 
III. RESULTS AND DISCUSSION

\section{Fabrication Studies}

The fabrication of cemented carbides by sintering involves several steps, each with its own set of parameters. In developing a fabrication route for $\mathrm{NbC}_{x}-\mathrm{Co}$ materials, we followed the steps generally used to fabricate WC-Co. The goal was to develop a route that could easily be scaled up or adapted to commercial processing of insert materials.

Discussions were held with Mr. John Flsher, Progressive Carbide, Cypress, California, concerning detalls of their process. On the basis of these discussions, we Inftially used Carbowax 4000 as binder and ball milled powders in deoxidized, delonized water for 48 hours, and followed a pressing, dewaxing, and sintering schedule that was similar to that used at Progressive. When difficulties were encountered in processing, other powders were prepared using methanol instead of water. Some powders were milled in a planetary ball mill, and some were spray dried rather than evaporatively drled. No consistent differences were found between these powders, and planetary milling was adopted because it could be performed in a much shorter time. We did not find any evidence that any oxidation caused by milling in water was significant probably because the subsequent heat treatment of pressed bodles in hydrogen to remove the wax binder also reduced any oxides.

Table 4 lists the batches of powders prepared during the project, with the detalls of binder, solvent, and milling procedure. Table 5 shows the fabrication data for one series of runs for the four cemented carbide compositions, all sintered at $1450^{\circ} \mathrm{C}$. 
Table 4

PREPARATION CONDITIONS FOR NbC-CO POWDERS

\begin{tabular}{|c|c|c|c|c|c|}
\hline Powder & Composition & & $\begin{array}{l}\text { iditive } \\
\text { (wt\%) }\end{array}$ & $\begin{array}{c}\text { Additive } \\
\text { Solvent } \\
\end{array}$ & $\begin{array}{l}\text { M1ling Me thod } \\
\text { and Tine (hr) }\end{array}$ \\
\hline A & $\mathrm{NbC}-10 \mathrm{Co}$ & 2 & Paraffin & Cyclohexane & BM/48 \\
\hline B & $\mathrm{NbC}_{0.83^{-10 C o}}$ & 2 & Paraffin & Cyclohexane & $B M / 48$ \\
\hline c & $\mathrm{NbC}-10 \mathrm{CO}$ & 2 & Carbowax & Cyclohexane & $\mathrm{BM} / 48$ \\
\hline D & $\mathrm{NbC}-10 \mathrm{Co}$ & 4 & Carbowax & Cyclohexane & $\mathrm{BM} / 48$ \\
\hline E & $\mathrm{NbC}-10 \mathrm{CO}$ & 2 & Carbowax & Water & $B M / 48$ \\
\hline F & $\mathrm{NbC}_{0.83^{-10 C o}}$ & 2 & Carbowax & Water & $B M / 48$ \\
\hline G & $\mathrm{NbC}-2 \mathrm{OCO}$ & 2 & Carbowax & Water & $B M / 48$ \\
\hline H & $\mathrm{NbC}_{0.83^{-20 C o}}$ & 2 & Carbowax & Water & $\mathrm{PM} / 12$ \\
\hline $\mathrm{H}_{1}$ & 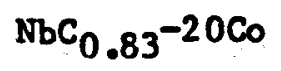 & 2 & Carbowax & Water & $\mathrm{PM} / 12$ \\
\hline $\mathrm{H}_{2} \mathrm{~b}$ & $\mathrm{Nb}_{0.83^{-20 C o}}$ & 2 & Carbowax & Water & $\mathrm{PM} / 12$ \\
\hline$F_{1}^{b}$ & $\mathrm{NbC}_{0.83^{-10 C o}}$ & 2 & Carbowax & Water & $\mathrm{PM} / 12$ \\
\hline $\mathrm{H}_{3}^{\mathrm{b}}$ & $\mathrm{Nb}_{0.83^{-10 C o}}$ & 2 & Carbowax & Methanol & $\mathrm{PM} / 12$ \\
\hline$I^{b}$ & $\mathrm{NbC}-20 \mathrm{Co}$ & 2 & Carbowax & Methanol & $\mathrm{PM} / 12$ \\
\hline $\mathrm{J}^{\mathrm{b}}$ & $\mathrm{NbC}_{0.83^{-10 C o}}$ & 2 & Carbowax & Methanol & $\mathrm{PM} / 12$ \\
\hline $\mathbf{K}$ & $\mathrm{NbC}-10 \mathrm{Co}$ & 2 & Carbowax & Methanol & $\mathrm{PM} / 12$ \\
\hline $\mathbf{M}$ & $\mathrm{NbC}-10 \mathrm{Co}$ & 2 & Carbowax & Me thanol & PM/ 6 \\
\hline $\mathbf{W}$ & $\mathrm{NbC}-10 \mathrm{Co}$ & & - & Water & $\mathrm{PM} / 4$ \\
\hline $\mathrm{x}$ & $\mathrm{NbC}_{0.83^{-10 C o}}$ & & - & Water & $\mathrm{PM} / 4$ \\
\hline $\mathbf{Y}$ & $\mathrm{NbC}_{0.83^{-10 C o}}$ & 2 & Carbowax & Water & PM/4 \\
\hline $\mathbf{z}$ & ${ }^{\mathrm{NbC}} \mathrm{C}_{0.83^{-20 \mathrm{Co}}}$ & & - & Water & PM/4 \\
\hline
\end{tabular}

a $B M=b a 11$ m111; $P M=$ planetary m111.

b All powders were evaporatively dried except $\mathrm{H}_{2}, \mathrm{~F}_{1}, \mathrm{H}_{3}, \mathrm{I}$, and $J$. 
Iable 5

PABRICATION DATA POR COELTEO nLOBIUA CAREIDES

SINTERED AT IAP SAME TERPERATUR

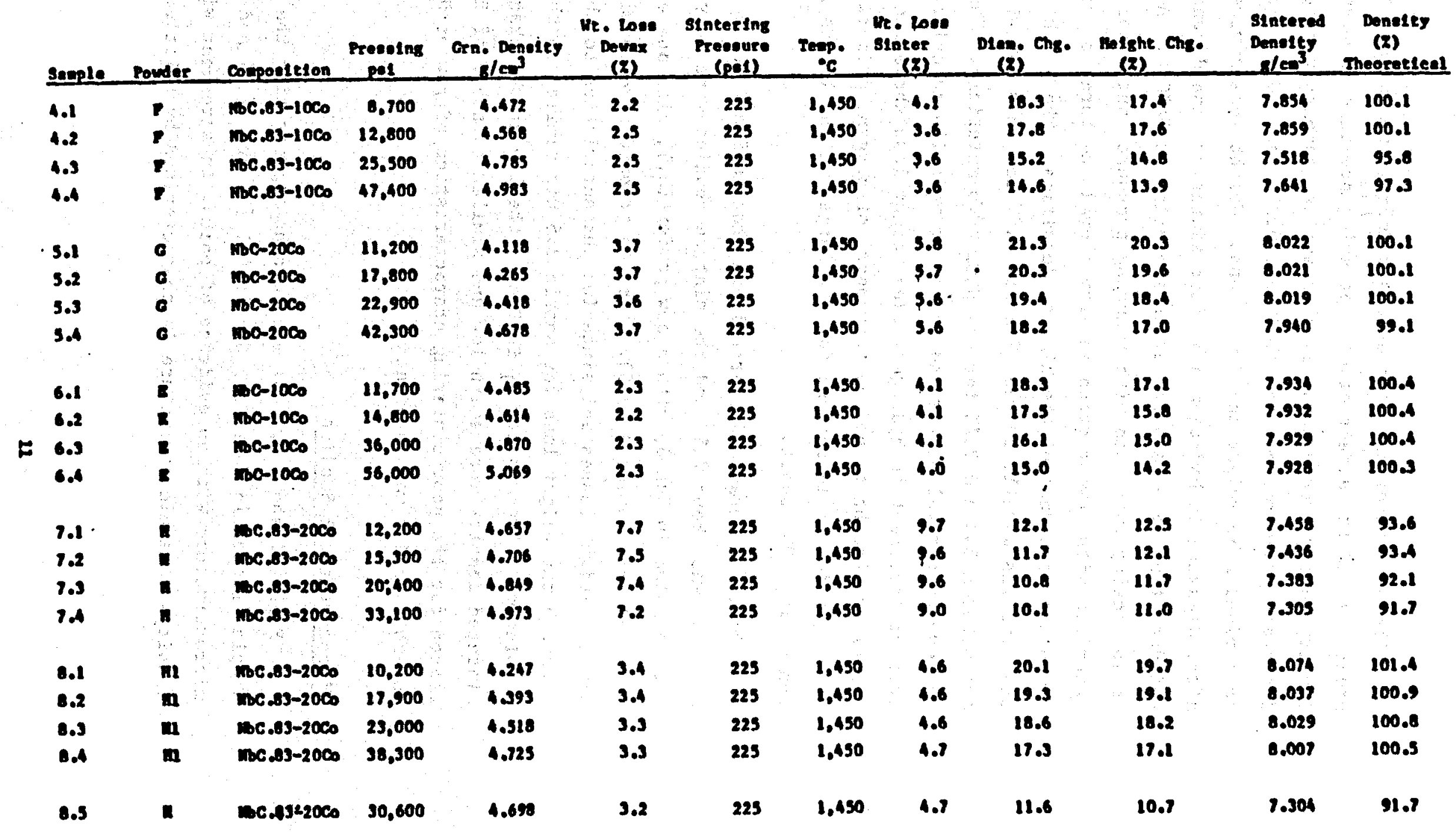


The purpose of this serles was primarlly to explore the dewaxing procedure and the effect of cold pressing pressure on dimensions and density during processing. In this series, samples were processed at different pressures between 8000 and 60,000 ps1. Green densities were determined from weight and dimensions. Weight losses were monitored after dewaxing in hydrogen and after sintering, and dimensional changes and densities were measured after sintering at $1450^{\circ} \mathrm{C}$. As expected, the green density increased with pressing pressure, but after sintering the materials with lowest green density showed the largest decrease in dimensions and reached the highest densities. The weight loss after dewaxing was usually between 2.2 and $2.5 \%$ for both $\mathrm{NbC}_{\mathrm{x}}-10 \mathrm{Co}$ materials and between 3.3 and $3.7 \%$ for the $\mathrm{NbC}_{\mathrm{x}}-20 \mathrm{Co}$ materlals. The weight $105 \mathrm{~s}$ was due to removal of wax and any other volatile materlal produced by the thermal treatment in hydrogen. The weight loss above the 2 wt\% of wax binder is thought to be due to removal of oxygen, primarily from the cobalt, which would account for the larger weight losses in the samples containing $20 \%$ cobalt.

Powder $H$ behaved differently in that in Run 7 the weight loss on dewaxing was about $7.5 \%$ and the sintered bodies were very porous. Run 7 was repeated in Run 8 , with a new powder $\left(\mathrm{H}_{1}\right)$, with one extra sample prepared from powder $\mathrm{H}(8.5)$. Samples prepared from powder $\mathrm{H}_{1}$ showed similar weight losses and sintering characteristics to those of Run 5. Although the weight loss for sample 8.5 was similar to that of the samples made from powder $\mathrm{H}_{1}$ in Run 8 , the linear shrinkage and the sintered density were again low and similar to those of Run 7. The reason for the poor sintering characteristics of powder:H was not found and this powder was abandoned.

Microstructural Studies

Figure 1 shows optical micrographs 1llustrating the main features of samples 1isted in Table 5. Sample 4.1 [Figure 1(a)] had a uniform microstructure with no evidence of pores, in agreement with the measured density. The microstructure is characterized by relatively continuous, 


\section{Figure 1}

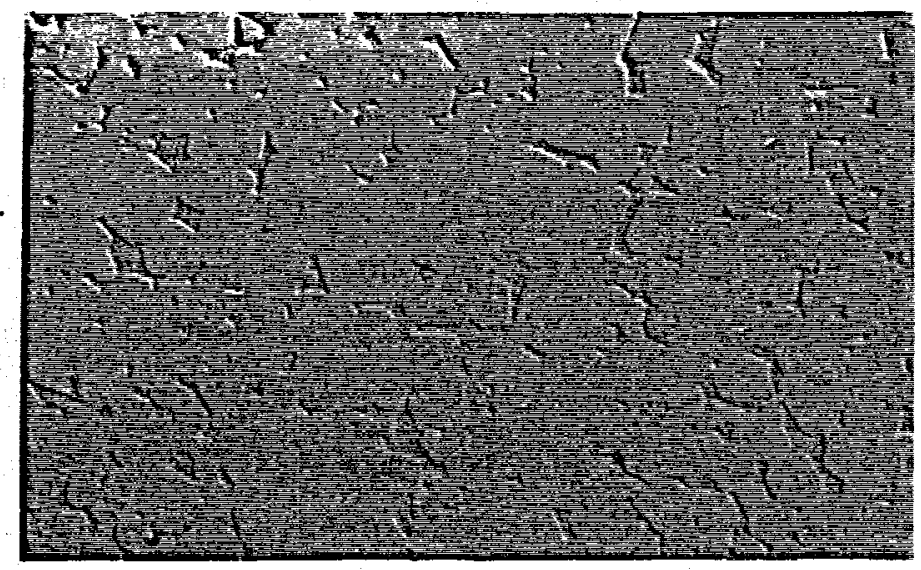

(a)

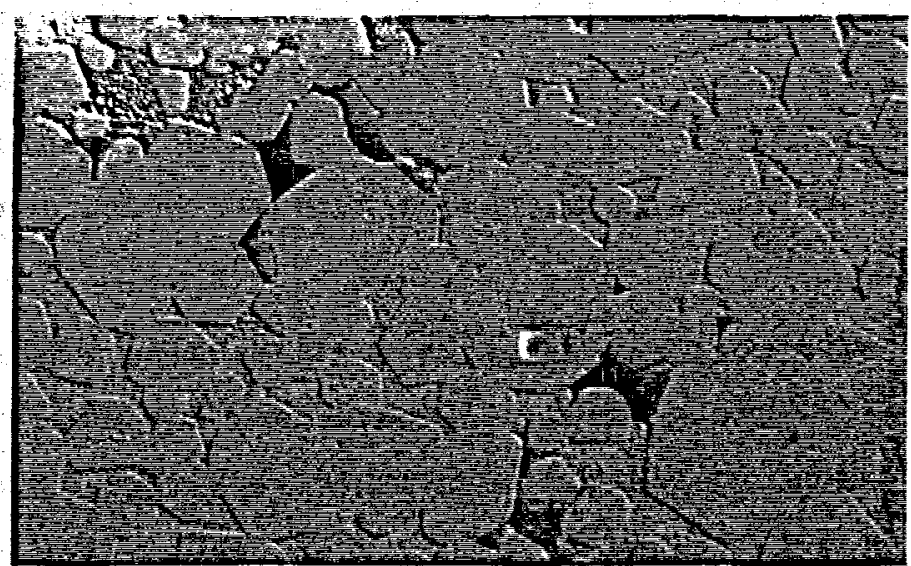

(b)

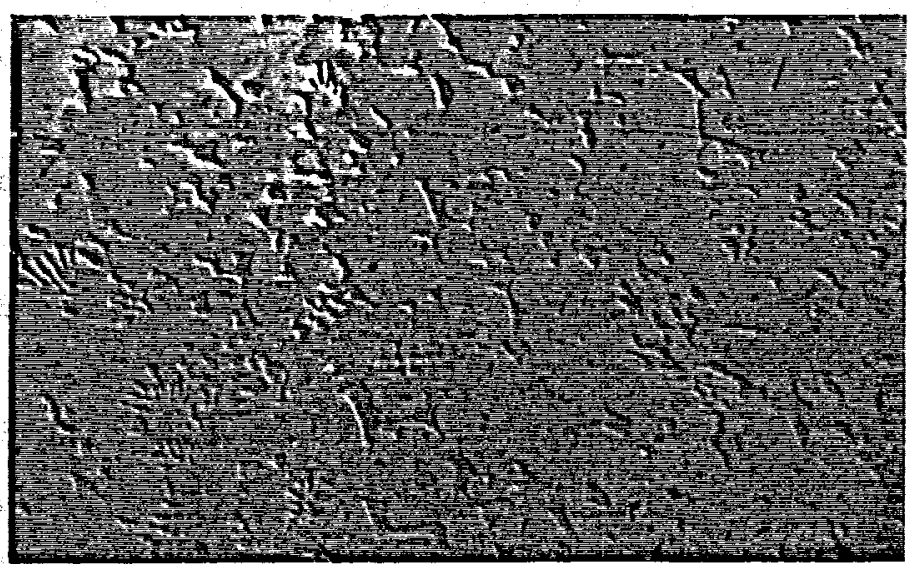

(c)

\section{$20 \mu \mathrm{m}$ \\ JP-8023-1}

FIGURE 1 MICROSTRUCTURES NbC $x$-Co MATERIALS SINTERED AT $1450^{\circ} \mathrm{C}$

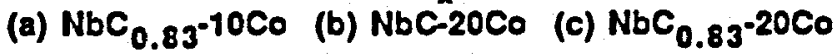


interconnected carbide grains. Most carbide/cobalt boundaries are curved. The few planar boundaries are probably high symetry planes [e.g, $(100) \cdot \mathrm{NbC}$, which tend to form when single crystals are grown from dilute solution. The grain size is about $15 \mathrm{~km}$. In many examples three grains grew together, apparently totally excluding cobalt. This microstructure indicates that liquid phase sintering occurred relatively readily. However, some samples in this series and others in Table 5 contained pores that were extensive in some cases. The form of the porosity was generally the same in all samples fabricated on this project and is illustrated in Figure 1b. The pores are in the cobalt regions. The carbide grain sizes and shapes are the same in porous and in porefree regions, suggesting that liquid cobalt binders was in the pores at least during part of the sintering. It was also possible that there was a local wetting problem or that the sintering temperature was not high enough.

A varlety of structures were observed in the binder phase. In Figure $1(b)$ most of the binder is featureless, but some regions etched differently, suggesting a different composition or even a multiphase binder. Such binder structures were often assoclated with regions of

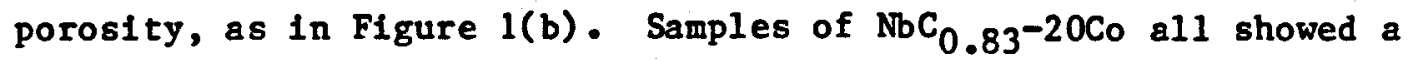
eutectic structure in the binder phase, as shown in Figure $1(\mathrm{c})$.

The next series of experiments was designed to evaluate the effect of sintering temperature on microstructure and density of sintered materials. Sets of samples were pressed and sintered at $1400^{\circ}, 1450^{\circ}$, and $1500^{\circ} \mathrm{C}$. The processing details are given in Table 6. Figure 2 shows micrographs of series 10 samples sintered at $1400^{\circ} \mathrm{C}$ and allows a direct comparison between the sintering characteristics of samples containing stolchiometric and substoichiometric $\mathrm{NbC}$. It was consistently found that

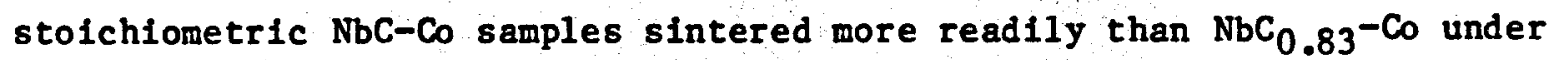
any conditions. The carbide grain size is clearly larger in the stoichiometric samples [Figures $2(a)$ and $(c)$ ] but does not depend on Co content. The substoichiometric samples showed significant porosity 


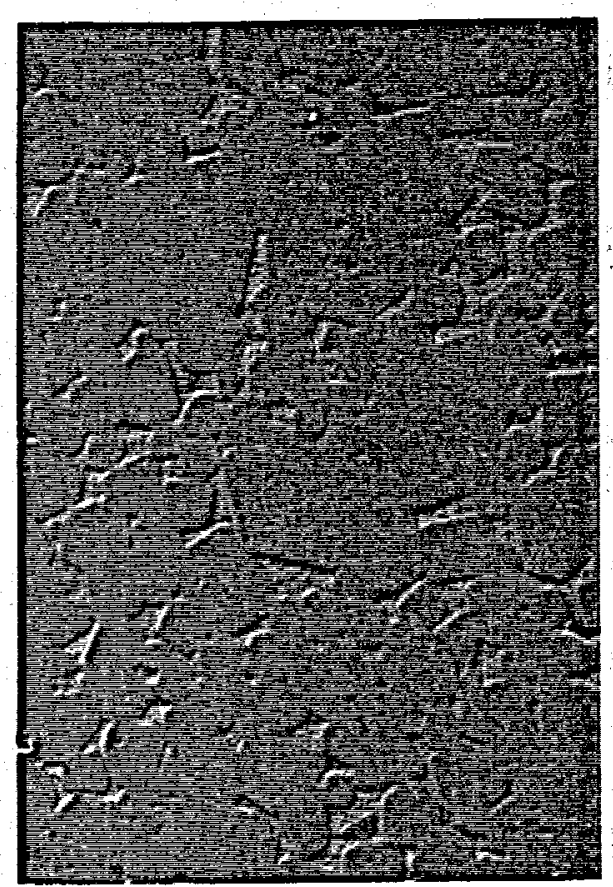

(a)

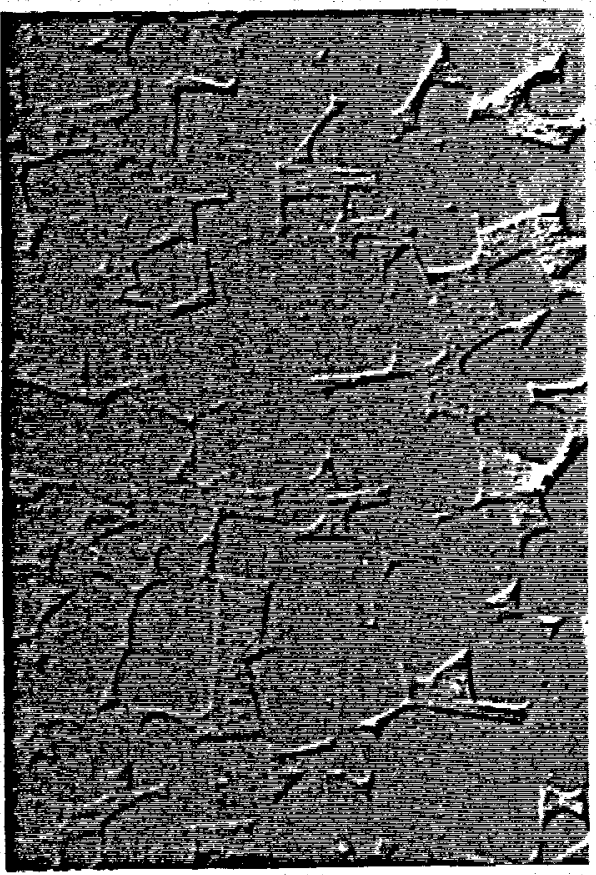

(c)

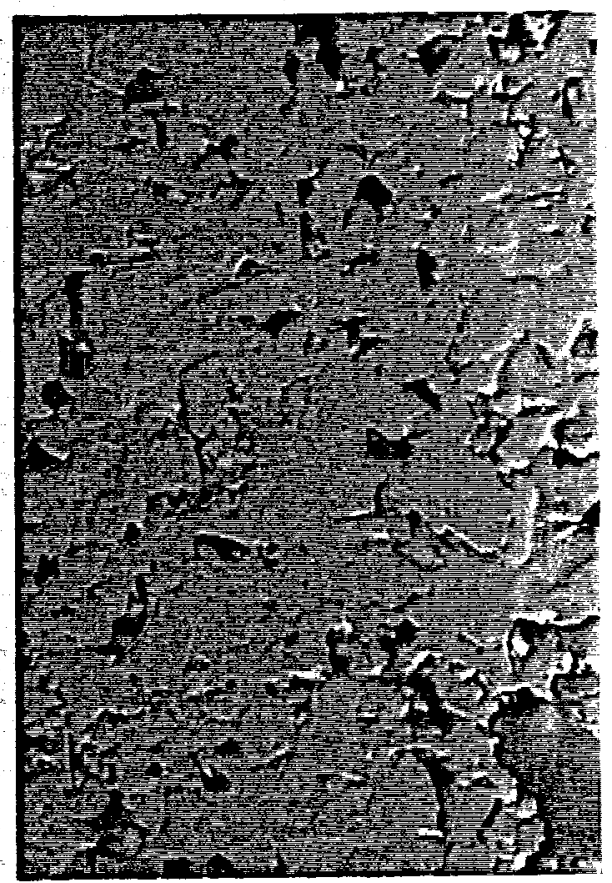

(b)

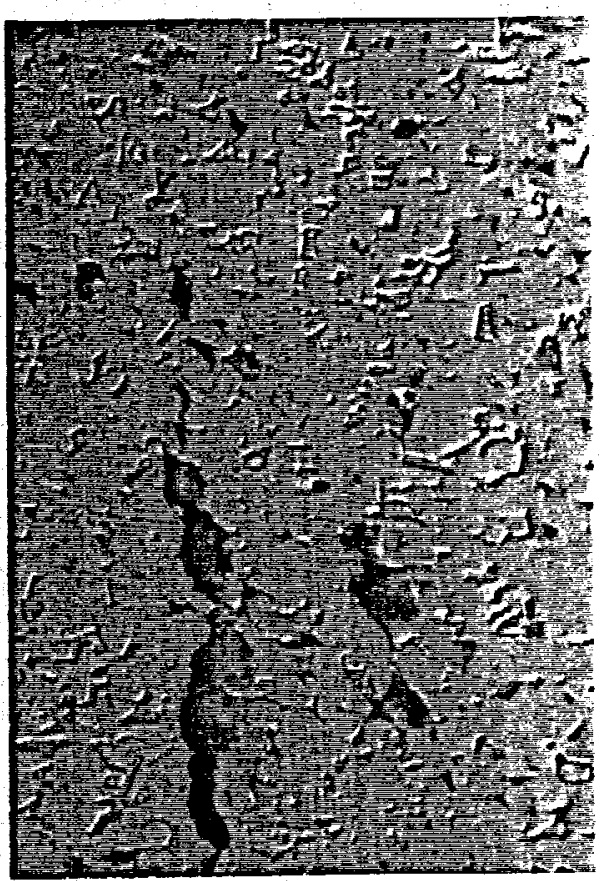

(d)

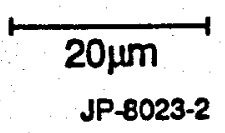

FIGURE 2 MICROSTRUCTURES OF NbC $x$-Co MATERIALS SINTERED AT $1400^{\circ} \mathrm{C}$

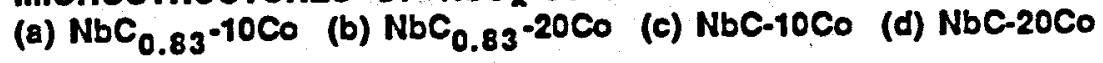


Table 6

PABRICATION DATA POR CERETTED nTOATOM CARStDES

SINTERed AT vaRlovs tenteratures

\begin{tabular}{|c|c|c|c|c|c|c|c|c|c|c|c|c|}
\hline Senple & Pouder & Cospontelon & $\begin{array}{c}\text { Presoluse } \\
\text { pel }\end{array}$ & 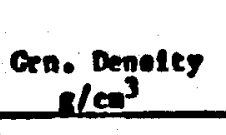 & $\begin{array}{c}\text { Me. Loses } \\
\text { Dewax } \\
\text { (2) }\end{array}$ & $\begin{array}{c}\text { Sintertng } \\
\text { Presoure } \\
\text { (pel) }\end{array}$ & $\begin{array}{c}\text { Temp. } \\
\circ C \\
\end{array}$ & $\begin{array}{r}\text { Me. lose } \\
\text { sinter } \\
(z) \\
\end{array}$ & $\begin{array}{c}\text { D1en. Che。 } \\
\text { (2) }\end{array}$ & $\begin{array}{c}\text { helght Che. } \\
\text { (z) }\end{array}$ & $\begin{array}{r}\text { Slarored: } \\
\text { Denofty } \\
\text { rlee }\end{array}$ & $\begin{array}{l}\text { Doneles } \\
\text { (2) } \\
\text { Theoreteel }\end{array}$ \\
\hline 9.1 & $\mathrm{E}$ & $n c-1000$ & 25,300 & 4.8 & 2.2 & 223 & 1,300 & 4.2 & 17.0 & 13.7 & 7.8 & 99.1 \\
\hline 9.2 & $P$ & $M O C .83-1000$ & 20,100 . & 4.8 & 2.6 & 223 & 1,900 & 3.6 & 16.2 & 16.3 & 7.8 & 99.7 \\
\hline 9.3 & c & $m b c-20 c 0$ & 28,100 & 4.3 & 3.5 & 223 & 2,500 & 3.5 & 10.9 & 18.9 & 1.9 & 90.1 \\
\hline 9.4 & m! & $m B C, 23-2006$ & 29,900 & 4.6 & 3.4 & 223 & 1.300 & 4.9 & 10.5 & 10.8 & 7.9 & 98.5 \\
\hline 10.1 & $\approx$ & $0-1060$ & 26,500 & 4.1 & 2.2 & 223 & 1,400 & $3.9^{\circ}$ & 17.1 & 15.6 & 8.0 & 99.1 \\
\hline 10.2 & 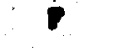 & Medes-10co & 26,000 & 4.8 & 2.5 & 223 & 1.400 & 3.3 & 14.6 & 14.3 & 7.3 & 92.8 \\
\hline 10.3 & c & $m b c-20 c 0$ & 25,500 & 4.4 & 3.4 & 225 & 1,400 & 3.1 & 19.6 & 18.6 & 7.9 & 90.5 \\
\hline 10.4 & $m$ & $m c .83-2000$ & 23,500 & 4.6 & 3.5 & 223 & 1.400 & 4.6 & 17.5 & 16.7 & 7.7 & 96.7 \\
\hline 11.1 & $\nabla$ & $D C .83-1000$ & 28,100 & 4.8 & 2.5 & 43 & 1,450 & 3.2 & 15.3 & 14.9 & 7.3 & 93.0 \\
\hline 11.2 & - & $m a-2000$ & 13,800 & 4.2 & 3.4 & 45 & 1.450 & 3.3 & 20.4 & 20.3 & 8.0 & 99.3 \\
\hline 11.3 & c & $m c-2000$ & 29,600 & 4.4 & 3.4 & 45 & 1.450 & 5.2 & 19.3 & 16.1 & 1.9 & 99.1 \\
\hline 11.04 & $\mathbf{m}$ & $m c 003-2006$ & 11,200 & 4.2 & 3.6 & 43 & 8,490 & 4.8 & 20.0 & 19.5 & 7.9 & 98.6 \\
\hline 11.5 & $m$ & $106.03-2000$ & 25,300 & 4.5 & 3.3 & 45 & 1,450 & 0.5 & 10.3 & 18.6 & 1.8 & 98.1 \\
\hline
\end{tabular}


[F1gures 2(b) and (d)], and again a eutectic structure was prominent in

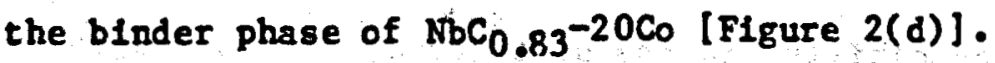

Sim1lar features were observed in the serles 9 samples sintered at $1500^{\circ} \mathrm{C}$, except that the grain size was larger in the stoichlometric materials and the porosity was much less in the substoichiometric samples. These observations confirmed that the stolchiometric NbC-Co materials could be sintered relatively readily between $1400^{\circ}$ and $1500^{\circ} \mathrm{C}$. However, the substolchiometric materials, which were of primary Interest, were difficult to densify at any temperature, and the appearance of the eutectic structure in $\mathrm{MbC}_{0.83^{-2}} 0 \mathrm{Co}$ samples was an additional complication. In addition, comparison of beries 10 and 11 $s$ uggested that the use of higher pressure In the second half of the sintering cycle had no discernable effect on microstructure or density of 6amples sintered at $1450^{\circ} \mathrm{C}$. However, the high pressure cycle was continued In most subsequent runs because we expected that a fimilar procedure would be used for samples processed at Progressive Carbide.

\section{Commercial Processing}

Eight pressed samples and sufficlent powder to prepare a further $81 x$ samples were sent to Progressive Carbide for processing. The two sets of samples were dewaxed using Progressive's standard procedure for WC-Co pressed with Carbowax, and each set was sintered in separate runs at $1400^{\circ} \mathrm{C}$ with a standard production run of WC-Co specimens. It was estimated that the porosities of the $61 x$ samples pressed and sintered at Progressive were about $10 \%$, and the densities were therefore not measured. The eight samples pressed at SRI were better. Two samples of

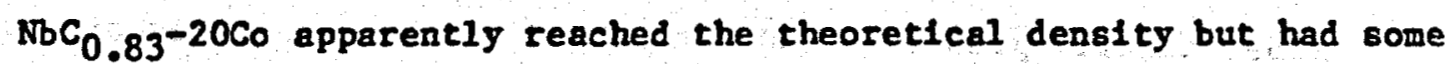
areas of volds near the specimen surfaces. The remaining samples all had densitles of about $96 \%$ of the theoretical value and correspondingly large areas of volds were visible in the microstructure. As expected, the propensity of small anguler carbide grains suggested that little 11quid phase sintering had occurred. Although the sintering temperature of $1400^{\circ} \mathrm{C}$ was somewhat low for the substolchiometric carbides, it was 
surprising that the stoichlometric materials did not sinter well.

The nonreproducibility in the sintered densities had several possible causes. The main ones considered were poor distribution of the wax binder and secondary reactions in liquid phase sintering that might affect solubility or wetting behavior. Three powders $(W, X$, and $Z$ in Table 4) were milled without any binder. Samples of powders $Z, Y$, and

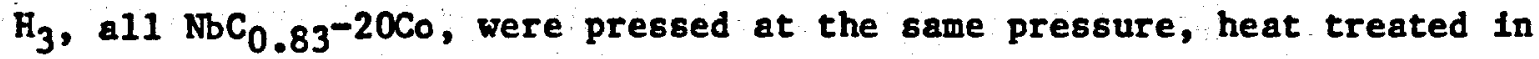
the dewaxing furnace under hydrogen, and sintered at $1450^{\circ} \mathrm{C}$. The three samples all reached the theoretical density and their microstructures were indistinguishable. These results suggested that the problems of nonreproduciblifty were not related to the milling and green stage processing. In a further run of nine specimens, four did not contain the wax binder and 80 were not heat treated in hydrogen with the five waxcontaining specimens. On sintering all samples together at $1450^{\circ} \mathrm{C}$, no systematic differences in sintered density were found for powders that originally contained or did not contain the wax binder. Densities ranged from 96 to $100 \%$ of thereotical for the respective carbide-cobalt compositions .

To confirm these findings, we sent samples of several powders to

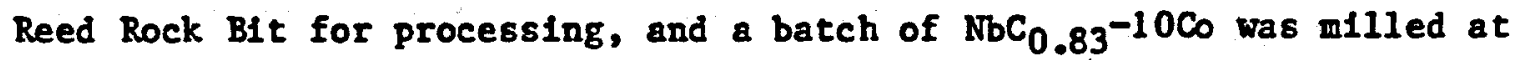
Reed using a paraffin wax binder and their standard milling procedure. At the same time further samples were processed at SRI by sintering and hot isostatic pressing to $2500 \mathrm{psi}$. Hot 1sostatic pressing 16 often used to close residual pores in batches of WC-Co that have not sintered satisfactorily. In some cases, the high pressure may overcome problems

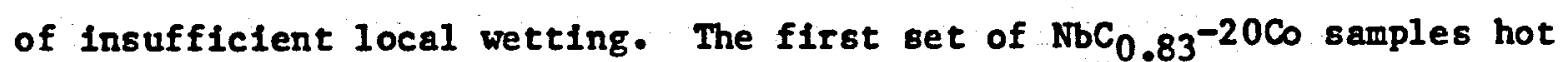
1sostatically pressed at SRI at $1500^{\circ} \mathrm{C}$ reached densities of $99.9,100$,

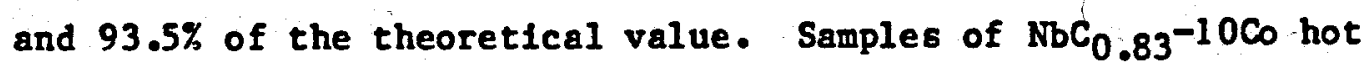
1sostatically pressed at $1400^{\circ} \mathrm{C}$ reached densitles of 96 to $100 \%$ of the theoretical value. Similar results were obtained at Reed using powders

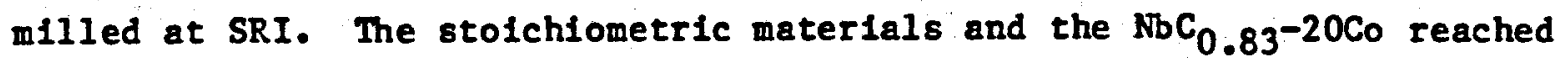

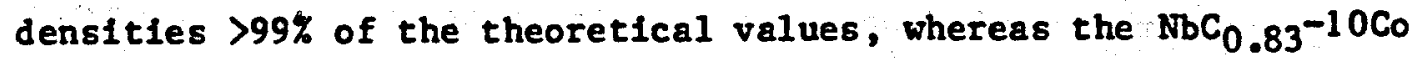
reached about $96 \%$ on sintering and $98 \%$ after hot isosatic pressing. 
Phase Composition Studies

These samples and others processed at SRI were examined metallograptically and by SEM. The blader phase composition varled considerably between specimens and at different areas within a single specimen. Both $W$ and $N b$ could be found in the predominantly $C o$ binder phase. It was generally found that those specimens that sintered well contained very little $\mapsto$. Usually the Mb content was also low in such

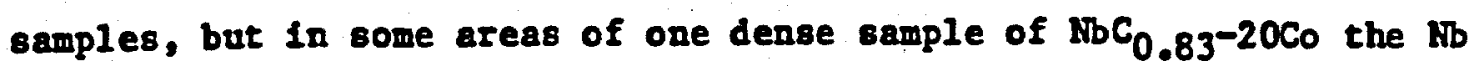
content was substantial, but the $N$ was just detectable above the

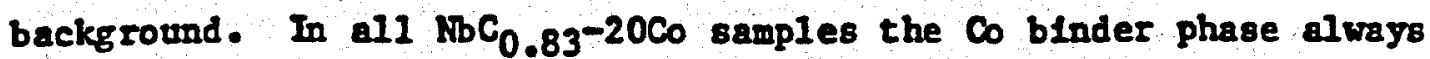
appeared to have a eutectic otructure. Selected porous samples were examined, and It was consistently found that the binder contained 81galflcant quantitles of $\mathrm{Wb}$ and $\mathrm{W}$ as evidenced by strong EDX peaks. Figure 3 shows a porous region of a sample of $\mathrm{MbC}_{0.83}-10 \mathrm{Co}$. Within the binder the $\mathrm{Mb} / \mathrm{W}$ rat10 varled from $1: 1$ to about $5: 1$. Tungsten probably arose from the WC balls used to m111 the powders. In addition, measurements of the lattlce parameter made on three substolchiometric dense specimens selected at random Indicated that the carbon content of the NbC had changed during processing to a value corresponding to an approximate composition $\mathrm{NbC}_{0.9}$. 


\section{Pigure 3}

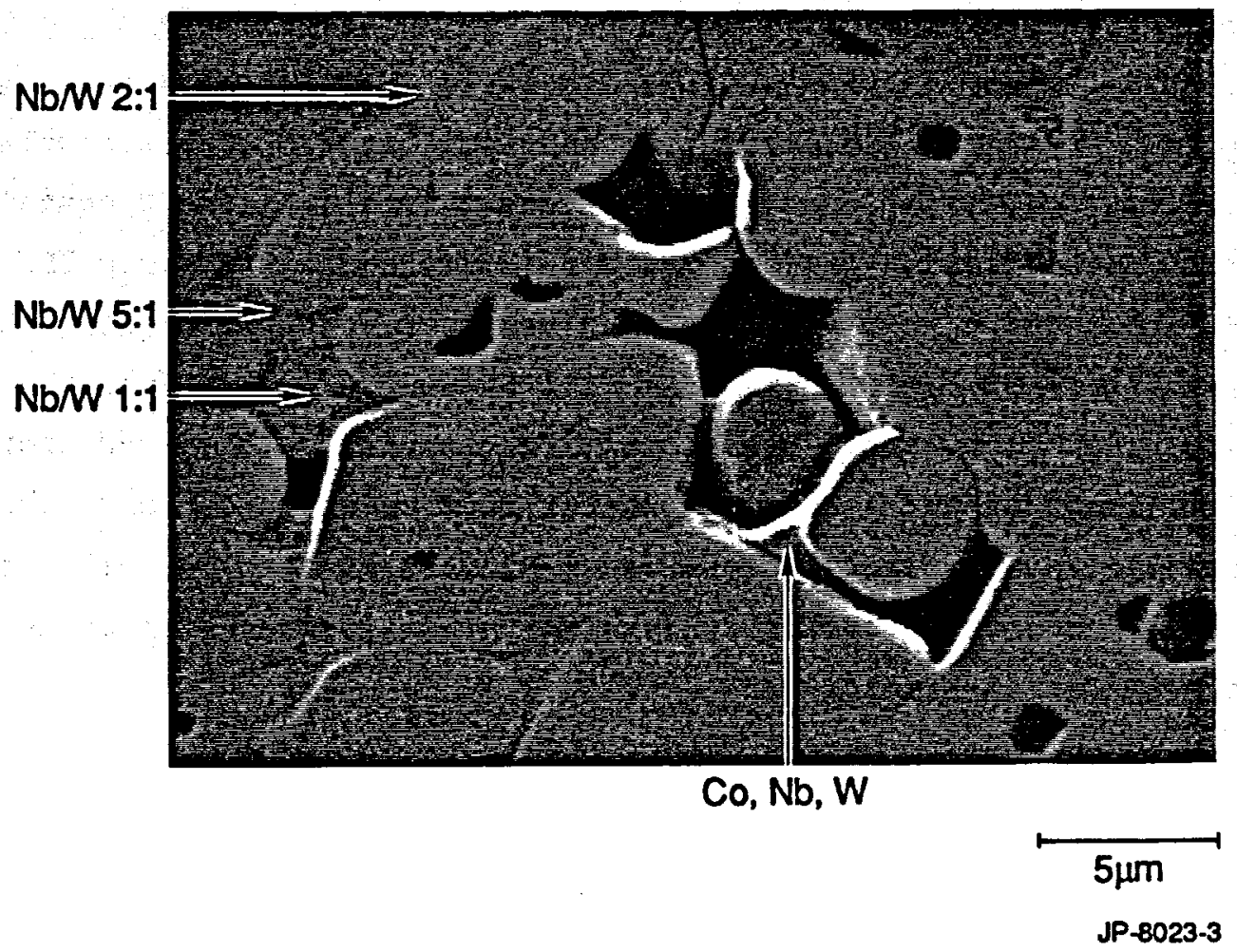

FIGURE 3 POROUS REGION IN NbC $0.83^{-10 C o}$ SINTERED AT $1450^{\circ} \mathrm{C}$ 
Evaluation of Toughness, Hardness and Wear Resistance

Hot isostatic pressing (HIP) at pressures up to 2500 psi was generally beneficial in the processing of $\mathrm{NbC}_{0.83}-10 \mathrm{Co}$. Approximately 15 HIP runs were performed to explore the temperature range $1375^{\circ}$ to $1450^{\circ} \mathrm{C}$, using a single batch of $\mathrm{NbC}_{0.83^{-1}} 0 \mathrm{Co}$ containing 2 wt\% paraffin wax, milled at Reed Rock Bit. Although some inconsistencies were evident, the majority of specimens had densitles of $99 \%$ or greater for processing temperatures between $1420^{\circ}$ and $1450^{\circ} \mathrm{C}$. Four samples were sent to Terratek for short-rod fracture toughness tests, and four others were sent to Dresser Industrles for wear testing.

The short-rod fracture toughness values for $\mathrm{NbC}_{0.83^{-10 C o} \text { samples }}$ were $6.00,6.33,6.23,5.45 \mathrm{MPa} \frac{1}{2}$. The 1ongltudinal fracture faces were polished and longitudinal and diametral hardness traces were made. No significant changes in hardness were observed across the samples. In the prevlous project, hot-pressed samples showed high hardness near the surface and a tendency to longltudinal hardness gradients that was ascribed to corresponding density gradients. Mean hardness values were $13.3,13.0,13.1$, and $13.4 \mathrm{GPa}$ for the four short-rod samples. These values were considerably lower than those found for hot-pressed $\mathrm{MbC}_{0.83^{-}}$ 10Co samples prepared in the prevlous project although the toughness values were similar.

Table 7 shows the wear test results obtained at Dresser Industries, together with data on hot-pressed samples. The data that are averages of six runs per sample are consistent for the four sintered/hot

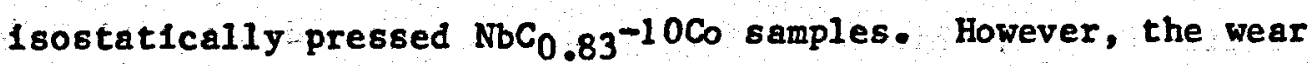
resistances of these samples are disappointingly low compared with the hot-pressed samples of nominally the same composition, tested previously. An examination of wear surfaces by SEM showed preferential $10 s s$ of the binder phase and microfracture of the carbide grains. In the previous study uneven wear of the phases and microfracture were thought to be assoclated with lower wear resistance, whereas the most wear resistant materials showed relatively even wear features and limited microfracture. 
Table 7

WEAR RES ISTANCE OF CEMENTED CARBIDES

\begin{tabular}{ccc}
$\begin{array}{c}\text { Specimen } \\
\text { No. }\end{array}$ & $\begin{array}{c}\text { Nominal } \\
\text { Composition }\end{array}$ & $\begin{array}{c}\text { Wear Resistance } \\
\text { Number }\end{array}$ \\
\hline 29.2 & $\mathrm{NbC}_{0.83^{-10 C o}}$ & 428 \\
30.2 & $\mathrm{NbC}_{0.83^{-10 C o}}$ & 445 \\
30.3 & $\mathrm{NbC}_{0.83^{-10 C o}}$ & 431 \\
30.4 & $\mathrm{NbC}_{0.83^{-10 C o}}$ & 468 \\
HP85 & $\mathrm{NbC}_{0.83^{-10 C o}}$ & 2065 \\
HP86/87 & $\mathrm{NbC}_{0.83^{-10 C o}}$ & 1866 \\
HP84 & ${\mathrm{NbC}-20 \mathrm{Co}^{-10}}$ & 376 \\
HP89 & $\mathrm{NbC}_{0.83^{-20 C o}}$ & 536
\end{tabular}

\section{General Discussion}

The low values of wear resistance are consistent with the lower hardness levels noted above. The difference in behavior between the sinter/hot isostatically pressed materials and the hot-pressed materials of the previous work is probably due to a difference in composition of the carbide. As noted above in the studies of binder phase composition, the lattice parameter of dense substolchiometric NbC-Co corresponded to a composition $\mathrm{NbC}_{0.9}$, which is softer than the expected material $\mathrm{Nb}_{0.83}$.

It is 1ikely that the compositions of the carbide and the cobalt binder phase were very sensitive to the conditions during sintering. Both $\mathrm{NbC}_{\mathrm{x}}$ and $\mathrm{WC}$ impurities can dissolve in the cobalt. Also, the carbon content of the binder depends on carbon arising from the furnace environment and that available in the form of $\mathrm{WC}, \mathrm{NbC}_{0.83}$, or $\mathrm{NbC}$. Al though WC is soluble in $C 0$ and in $\mathrm{NbC}$, the EDX analyses suggested that $W$ remained in the binder phase. The distribution of carbon in the sintered $\mathrm{NbC}_{0.83^{-C o}}$ could not be determined, but it is possible that $\mathrm{NbC}_{\mathrm{X}}$ 
produced by solution and precipitation could be stoichiometric, whereas the grain cores could be $\mathrm{NbC}_{0.83^{\circ}}$. It was observed that stolchiometric $\mathrm{NbC}-\mathrm{Co}$ sintered relatively easily. Thus successful sintering of $\mathrm{NbC}_{0.83^{-}}$ $10 \mathrm{Co}$ might depend on the growth of a layer of stoichlometric NbC so that the wetting or transport kinetics become favorable. Other elements dissolved in the cobalt binder phase will also affect its wetting properties. If the concentration of elements in the binder phase changes appreclably during the sintering period, it is possible that the 11quid phase sintering process could be inhibited. It was beyond the resources and scope of the project to investigate these effects in any depth. However, we suggest that sintering of the substolchlometric materials was difficult because the carbon content could not be controlled well

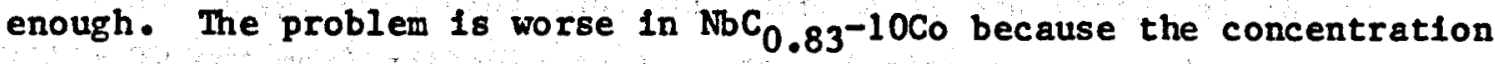
of elements in the binder phase could be twice as high as in materials containing $20 \%$ Co. Time at the sintering temperature is probably critical and should be kept to a minimum. 
IV CONCLUSIONS

A series of $\mathrm{NbC}_{\mathrm{x}}-\mathrm{Co}$ materials was prepared by sintering and hot isostatic pressing. The stoichiometric $\mathrm{NbC}-10 \mathrm{Co}$ and $\mathrm{NbC}-20 \mathrm{Co}$ were sintered to high density relatively easily, whereas materials based on $\mathrm{NbC}_{0.83}$ were difficult to sinter. This difficulty is related to control of carbon content during processing. The carbon content of dense samples prepared from $\mathrm{NbC}_{0.83}$ and $\mathrm{Co}_{0}$ Increased to an average composition of approximately $\mathrm{NbC}_{0.9}$ during processing. This higher carbon-content carbide is softer and less wear resistant than $\mathrm{NbC}_{0.83}$, which was confirmed by the mechanical tests. Contamination from the WC milling balls complicated the processing further. On the other hand, the microstructures were uniform throughout all the dense samples that were examined.

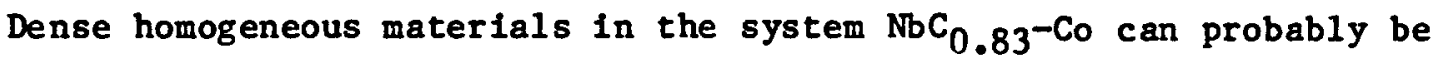
produced by more careful control of the processing conditions. In particular, powders should be milled with NbC-Co milling balls to avold $W$ contamination of the binder and excess $\mathrm{C}$ in the $\mathrm{NbC}_{0.83^{\circ}}$ In addition, the processing time at temperature should be kept to a minimum to avoid excessive solution of $\mathrm{Nb}$ in the $\mathrm{C}_{0}$ and increase of $\mathrm{C}$ in the $\mathrm{NbC}_{0.83}$. Sintering for 5 minutes at $1420^{\circ}$ to $1450^{\circ} \mathrm{C}$ followed by hot isostatic pressing for the same time in this temperature range should produce acceptable materials. In this case the hardness and wear resistance values are expected to reach those obtained previously on samples prepared by hot pressing. 
DISTRIBUTION :

DOE/TIC-4500-UC-253 (10)

Dr. J. J. Azar

Tulsa University Drilling

Research Projects

Petroleum EngIneering Dept.

North Campus Drill Bldg.

2450 Marshall

Tulsa, OK 74110

Bill Baker

Smith Tool

P. O. Box C-19511

Irvine, CA 92713

Ed Bingman

Shell Oil Co.

Two Shell Plaza

P. O. Box 2099

Houston, TX 77001

Alan Black

Drilling Research Laboratory

University Research Park

400 Wakara Way

Salt Lake City, UT 84108

Gerald R. Boyle

Anco Diamond Composite Corp. 545 Fifth Ave.

New York, NY 10017

Ben Bradford

Dowell

P. O. Box 2710

Tulsa, OK 74102

John Cheatham

Rice University

Mechanical Engineering Dept.

P. 0. Box 1892

Houston, TX 77001

David Clark

Conoco Production Research

P. O. Box 1267

Ponca City, OR 74603
Jim Combs

Geothermal Resourches Int'1., Inc.

1825 W. Grant, Sulte 900

San Mateo, CA 94402

Brett Davies

Huddy International

Suite 304

7061 S. University Blvd.

Littleton, CO 80122

Dr. Melvin Friedman

Center for Technophysics

and Dept. of Geology

College Station, TX 77843

Daniel Garcia

Tulsa University Drilling

Research Projects

Petroleum Engineering Dept.

North Campus Drill Bldg.

2450 Marshall

Tulsa, OK 74110

Louis Hibbs, Jr.

General Electric Co.

P. 0. Box 8, Bldg. K-1

Schenectady, NY 12301

Dr. Michael Hood

University of California

Dept. of Materials Science \&

Minerals Engineering

Berkeley, CA 94720

James Langford

Security Division

Dresser Industries

P. O. Box 2467

Dallas, IX 75224

B. J. LIvesay

Livesay Consultants

2613 Angel1 Ave.

San Diego, CA 92122

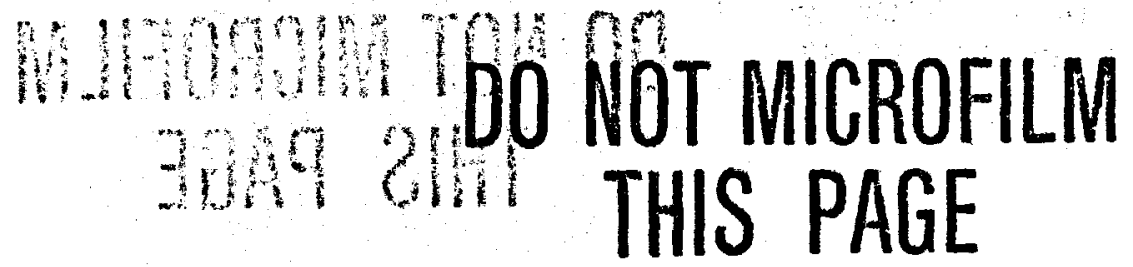


Ed Martin

Mobil Research \&

Development Corporation

Dallas Research Laboratory

13777 Midway Rd.

Dallas, TX 75224

Larry Matson

Stratabit

600 Kenrick, Suite Al

Houston, TX 77060

William Maurer

Maurer Engineering, Inc.

$10301 \mathrm{NW}$ Freeway

Suite 202

Houston, TX 77205

Keith Millheim

Amoco Production Company

Research Center

P. O. Box 591

Tulsa, OK 74102

Alfonso Ortega

Dept. of Aerospace \&

Mechanical Engineering

College of Engineering \& Mines

University of Arizona

Tucson, Arizona 85721

Gene Polk

P. O. Box 280

Sandia Park, NM 87047

Steve Pye

Union Geothermal Division

Union Oil Co. of California

Union Oil Center

461 S. Boylston

Los Angeles, CA 90017

Troy Reed

Conoco Production Research

P. O. Box 1267

Ponca City, OK 74603
John C. Rowley

Los Alamos National Laboratory

Mail Stop 462

Los Alamos, NM 87545

U.S. Dept. of Energy (2)

Geothermal Technologies Div.

Attn: Lew Pratsch

Marshall Reed

Forrestal Bldg., CE-324

1000 Independence Ave., SW

Washington, DC 20585

George P. Tennyson

DOE/ALO

P. O. Box 5400

Albuquerque, NM 87115

Sam Varnado

Titan-Spectron

2017 Yale Blvd., SE

Albuquerque, NM 87106

Bruce Walker

Drilling Research Laboratory

University Research Park

400 Wakara Way

Salt Lake City, UT 84108

Tom Warren

Amoco Production Company

Research Center

P. 0. Box 591

Tulsa, OK 74102

John Barr

NL Hycalog

Oldends Lane

Industrial Estate

Stonehouse, Gloucester

England GL10 3RQ

Rubin Feenstra

Shell Research B.V.

Volmerlaan 6

2288 GD Rijswijk ZH

The Netherlands

Jim Riechman

FlowDril Corporation

21414 - 68th Ave. S.

Kent, WA 98032

the

DO 


$\begin{array}{ll}3141 & \text { S. A. Landenberger (5) } \\ 3151 & \text { W. I. Klein (3) } \\ 3154-1 & \text { C. L. Ward for DOE/OSTI (8) } \\ 5260 & \text { J. R. Kelsey } \\ 6200 & \text { V. L. Dugan } \\ 6250 & \text { R. K. Traeger } \\ 6252 & \text { J. C. Dunn (5) } \\ 6252 & \text { J. T. Finger (20) } \\ 6252 & \text { D. A. Glowka (10) } \\ 6252 & \text { P. C. Lysne } \\ 6314 & \text { T. E. Hinkebein } \\ 8524 & \text { J. R. Wackerly }\end{array}$

\section{DO NOT MICROFLLM \\ THIS PAGE}

